\title{
Pengaruh Model Survey, Question, Reading, Reflect, Recite, Review Terhadap Keterampilan Membaca
}

\author{
N. K. A.D. Putri ${ }^{1}{ }^{*}$, Kt. Adnyana Putra ${ }^{2}$, DB. Kt. Ngr. Semara Putra ${ }^{3}$ \\ 1,2,3 Jurusan Pendidikan Guru Sekolah Dasar, Fakultas Ilmu Pendidikan, Universitas Pendidikan Ganesha Singaraja, Indonesia
}

\section{ARTICLEIN \\ $\mathrm{FO}$ \\ Article history: \\ Received 12 May \\ 2018 \\ Received in revised \\ form \\ 18 June 2018 \\ Accepted 16 July \\ 2018 \\ Available online 28 \\ August 2018}

Kata Kunci:

keterampilan

membaca, SQ4R.

Keywords:

reading skill, SQ4R

\begin{abstract}
A B STRAK
Penelitian ini bertujuan untuk mengetahui pengaruh model Survey, Question, Reading, Reflect, Recite, Review terhadap keterampilan membaca pada siswa kelas V SD Gugus Kompyang Sujana Kecamatan Denpasar Barat Tahun Ajaran 2017/2018. Jenis penelitian ini adalah penelitian eksperimen semu dengan rancangan nonequivalent control group design. Populasi penelitian ini adalah seluruh siswa kelas V SD Negeri di Gugus Kompyang Sujana Kecamatan Denpasar Barat sebanyak 638 orang yang tersebar menjadi 16 kelas. Sampel ditentukan dengan menggunakan teknik random sampling. Sampel dalam penelitian ini adalah siswa kelas VA SDN 12 Padangsambian sebanyak 42 orang sebagai kelompok eksperimen dan siswa kelas VA SDN 9 Padangsambian sebanyak 44 orang sebagai kelompok kontrol. Pengumpulan data dilakukan dengan menggunakan metode tes dengan bentuk tes objektif pilihan ganda biasa dan rubrik penilaian membaca nyaring. Data yang diperoleh dianalisis menggunakan uji-t (polled varians). Hasil penelitian menunjukkan bahwa $t_{\text {hitung }}=3,396$ sedangkan pada taraf signifikansi $5 \%$ dengan $\mathrm{dk}=84$ diperoleh nilai $t_{\text {tabel }}=2,000$ sehingga $t_{\text {hitung }}=3,396>t_{\text {tabel }}=2,000$. Adapun nilai rata-rata keterampilan membaca pada siswa kelompok eksperimen $(\bar{X}=79,64)$ lebih
\end{abstract} dari nilai rata-rata keterampilan membaca pada siswa kelompok kontrol $(\bar{X}=72,05)$. Dengan demikian dapat disimpulkan bahwa terdapat pengaruh yang model Survey, Question, Reading, Reflect, Recite, Review terhadap keterampilan membaca pada siswa kelas V SD Gugus Kompyang Sujana Kecamatan Denpasar Barat Tahun Ajaran 2017/2018.

\section{A B S T R A C T}

This research aimed to find out the effect of Survey, Question, Reading, Reflect, Recite, Review (SQ4R) model on the reading skill of $5^{\text {th }}$ grade students of SD Gugus Kompyang Sujana of Denpasar Barat subdistrict in the academic year 2017/2018. This research type was quasi experimental research with nonequivalent control group design. The population of this research was all students of of $5^{\text {th }}$ grade students in SD Gugus Kompyang Sujana of Denpasar Barat subdistrict in the academic year 2017/2018 amounted to 638 students which scattered into 16 classes. The samples were determined by using random sampling technique. The sample of this research were the students of $5^{\text {th }}$ A grade in SD Negeri 12 Padangsambian amounted 42 students as the experimental group and the students of $5^{\text {th }} \mathrm{A}$ grade in SD Negeri 9 Padangsambian amounted 44 students as the control group. The data were collected by using the test method in form of usual multiple choice objective test and the reading screeching column. The data was analyzed by using t-test. Result of the research shows that $t_{\text {count }}=3,396$ meanwhile at $5 \%$ significance level with $d f=84$ obtained $t_{\text {table }}=2,000$, so $t_{\text {count }}=$ $3,396>t_{\text {table }}=2,000$. The average value of reading skill on students as experimental group $(\bar{X}=79.64)$ was more than the average of reading skill on students as control group $(\bar{X}=72,05)$. So it can be concluded that there is an effect of Survey, Question, Reading, Reflect, Recite, Review model on the reading skill of $5^{\text {th }}$ grade students of SD Gugus Kompyang Sujana of Denpasar Barat subdistrict in the academic year 2017/2018.

Copyright (C) Universitas Pendidikan Ganesha. All rights reserved.

\footnotetext{
* Corresponding author.

E-mail addresses: ni.km.alit.dharma@undiksha.ac.id (N. K. A.D. Putri)
} 


\section{Pendahuluan}

Bahasa memiliki peran yang sangat penting dalam kehidupan. Salah satu peran utama bahasa dalam kehidupan sehari-hari adalah sebagai alat untuk berkomunikasi. "Bahasa merupakan suatu sistem simbol untuk berkomunikasi, meliputi daya cipta dan sistem aturan" (Dhieni, 2014:1.3). Runaitun (2015) juga menyebutkan bahwa bahasa merupakan rangkaian bunyi yang melambangkan suatu pikiran, perasaan, atau sikap. Berdasarkan pengertian tersebut dapat disimpulkan bahwa bahasa merupakan alat komunikasi yang berupa rangkaian bunyi yang melambangkan suatu pikiran, perasaan, atau sikap. Individu dapat menyampaikan informasi atau pesan berupa pikiran, perasaan, fakta, kehendak dengan menggunakan lambang bahasa. Agar individu dapat menggunakan bahasa dalam berinteraksi, maka ia harus memiliki kemampuan berbahasa yang baik. Sejalan dengan hal tersebut, Solehan (2014) menyatakan bahwa bahasa bertujuan untuk mengembangkan kemampuan berkomunikasi baik lisan maupun tulisan. Oleh sebab itu, pembelajaran bahasa sudah diajarkan saat anak memasuki usia sekolah dasar hingga perguruan tinggi.

Berdasarkan kurikulum pendidikan yang berlaku di Indonesia saat ini, yaitu Kurikulum 2013, Bahasa Indonesia termasuk ke dalam mata pelajaran yang terintegrasi dalam Kurikulum 2013. Hal ini sesuai dengan karakteristik pembelajaran Kurikulum 2013 yakni menggunakan pendekatan scientific dan pendekatan tematik-integratif. Fadlillah (2014) menyebutkan bahwa, pendekatan scientific ialah pendekatan pembelajaran yang dilakukan melalui proses mengamati (observing), menanya (questioning), mencoba (experimenting), menalar (associating), dan mengomunikasikan (communicating). Kegitan pembelajaran seperti ini dapat membentuk sikap, keterampilan, dan pengetahuan peserta didik secara maksimal.

Selain itu Fadlillah (2014:176) juga menyatakan bahwa "pendekatan tematik-terintegrasi dimaksudkan bahwa dalam pembelajaran tersebut dibuat per tema dengan mengacu karakteristik peserta didik dan dilaksanakan secara integrasi antara tema satu dengan yang lain maupun antara mata pelajaran satu dengan mata pelajaran yang lain".

Dalam pembelajaran Bahasa Indonesia, terutama di sekolah dasar (SD) tidak akan terlepas dari empat aspek keterampilan dasar berbahasa yaitu, menyimak, berbicara, membaca dan menulis. Keempat keterampilan berbahasa tersebut dipelajari dan dimiliki oleh siswa untuk berkomunikasi dalam kehidupan sehari-hari. Komunikasi lisan akan membangun keterampilan berbicara dan menyimak. Sementara komunikasi tulis akan membangun keterampilan menulis dan membaca.

Dari keempat keterampilan berbahasa, keterampilan membaca merupakan modal utama setiap individu dalam memperoleh informasi maupun wawasan secara tertulis. Susanto (2015) menyatakan, tujuan pelajaran bahasa Indonesia di SD antara lain bertujuan agar siswa mampu menikmati dan memanfaatkan karya sastra untuk mengembangkan kepribadian, memperluas wawasan kehidupan, serta meningkatkan pengetahuan dan kemampuan berbahasa. Adapun tujuan khusus pengajaran bahasa Indonesia, antara lain agar siswa memiliki kegemaran membaca, meningkatkan karya sastra untuk meningkatkan kepribadian, mempertajam kepekaan, perasaan, dan memperluas wawasan kehidupannya.

Berdasarkan pernyataan tersebut, kegemaran siswa dalam membaca termasuk dalam tujuan khusus pengajaran Bahasa Indonesia. Selain itu, aktivitas membaca dalam dunia pendidikan merupakan hal yang sangat penting, karena sebagian besar ilmu dan berbagai informasi diperoleh melalui kegiatan membaca, sehingga keterampilan membaca yang dimiliki oleh seseorang mempengaruhi wawasan pengetahuan yang dimilikinya.

Membaca merupakan suatu keterampilan berbahasa yang dipergunakan untuk berkomunikasi secara tidak langsung dengan orang lain. Bagi siswa keterampilan membaca merupakan modal dasar yang sangat penting. Apabila siswa kurang menguasai keterampilan membaca maka ia akan mengalami kesulitan dalam mempelajari mata pelajaran yang lainnya. Kegiatan membaca termasuk keterampilan berbahasa yang tergolong aktif-reseptif. Membaca disebut aktif karena dalam proses membaca terdapat keaktifan seseorang dalam mengeja, menyerap, atau mengolah apa yang dibaca, sehingga proses tersebut mengarah pada upaya memahami bahan atau materi bacaan yang dibacanya. Dalman (2013:8) menyebutkan bahwa membaca disebut reseptif, "artinya, si pembaca menerima pesan atau informasi yang disampaikan penulis dalam sebuah teks bacaan".

Membaca adalah suatu proses yang dilakukan serta dipergunakan oleh pembaca untuk memperoleh pesan, yang hendak disampaikan penulis melalui media kata-kata atau bahasa tulisan (Tarigan, 2015). Sedangkan menurut Dalman (2013:7), "membaca adalah proses perubahan bentuk lambang/tanda/tulisan menjadi wujud bunyi yang bermakna." Oleh sebab itu, kegiatan membaca sangat ditentukan oleh kegiatan fisik dan mental yang menuntut seseorang untuk menginterpretasikan simbolsimbol tulisan dengan aktif dan kritis sebagai pola komunikasi dengan diri sendiri, agar pembaca dapat menemukan makna tulisan dan memperoleh informasi yang dibutuhkan. 
Sedangkan Klein, dkk. (dalam Rahim, 2011) mengemukakan bahwa membaca mencakup (1) membaca merupakan suatu proses, (2) membaca adalah strategis, dan (3) membaca merupakan interaktif. Berdasarkan beberapa definisi tentang membaca tersebut, dapat dirangkum bahwa membaca adalah proses yang dilakukan oleh pembaca dalam mentransfer bentuk bahasa menjadi bunyi yang memiliki makna untuk memperoleh informasi yang dibutuhkan.

Ditinjau dari segi terdengar atau tidaknya suara si pembaca saat membaca, proses membaca terbagi menjadi dua jenis, yaitu membaca nyaring dan membaca dalam hati (Tarigan, 2015). Jenis membaca yang diteliti dalam penelitian ini adalah membaca nyaring dan membaca pemahaman.

Membaca nyaring adalah kegiatan membaca dengan melafalkan lambang-lambang bunyi bahasa dengan suara yang cukup keras. Membaca nyaring bertujuan agar seseorang mampu mempergunakan ucapan yang tepat, membaca dengan jelas dan tidak terbata-bata, membaca dengan tidak terus menerus melihat pada bahan bacaan, membaca dengan menggunakan intonasi dan lagu yang tepat dan jelas (Dalman, 2013).

Sedangkan membaca pemahaman (reading for understanding) adalah sejenis membaca yang bertujuan untuk memahami tentang standar-standar atau norma-norma kesastraan (literary standards), resensi kritis (critical review), dan pola-pola fiksi (patterns for fiction) (Dalman, 2013). (reading for understanding) adalah sejenis membaca yang bertujuan untuk memahami tentang standar-standar atau norma-norma kesastraan (literary standards), resensi kritis (critical review), dan pola-pola fiksi (patterns for fiction) (Dalman, 2013).

Iskandarwassid dan Dadang Sunendar (2016:245) mengatakan bahwa "keterampilan membaca pada umumnya diperoleh dengan mempelajarinya di sekolah". Pembelajaran membaca di sekolah perlu difokuskan pada aspek keterampilan memahami isi bacaan. Dalam hal ini, peran guru sangat besar pengaruhnya terhadap keterampilan siswa dalam memahami isi bacaan. Peran guru dalam proses pembelajaran, tidak hanya sebagai pengajar melainkan beralih sebagai pendidik, pelatih, maupun pembimbing siswa. Sudah menjadi kewajiban seorang guru untuk membimbing siswa sehingga dapat mengembangkan potensinya.

Berdasarkan hasil observasi yang dilakukan oleh peneliti di kelas V SD Gugus Kompyang Sujana Kecamatan Denpasar Barat tahun ajaran 2017/2018 pada tanggal 8 sampai dengan 9 Januari 2018, dapat diketahui bahwa keterampilan membaca pada siswa masih perlu dioptimalkan. Hal ini dilihat dari nilai raport siswa semester ganjil dalam mata pelajaran Bahasa Indonesia dari 637 siswa, sebanyak 49,76\% siswa sudah mencapai nilai Kriteria Ketuntasan Minimal (KKM), yaitu 75,00. Sedangkan sebanyak 50,24\% siswa belum mencapai nilai KKM. Hal tersebut dapat disebabkan oleh beberapa faktor, diantaranya pemahaman siswa terhadap suatu bacaan dan minat siswa dalam membaca masih perlu dikembangkan dan dioptimalkan. Siswa menganggap kegiatan membaca merupakan kegiatan yang membosankan apalagi dengan bacaan yang panjang. Selain itu, dengan adanya kemajuan teknologi siswa merasa dimudahkan dalam memperoleh informasi dan mengesampingkan kegiatan membaca, sehingga keterampilan siswa dalam memahami isi bacaan menjadi berkurang.

Setelah melakukan refleksi bersama guru, dirasakan oleh guru bahwa guru perlu menentukan strategi, pendekatan, maupun model yang inovatif agar proses pembelajaran menjadi lebih optimal. Dengan kondisi ini, guru membutuhkan kinerja yang lebih dalam meningkatkan keterampilan membaca pada siswa. Kegiatan membaca harus mampu menghubungkan antara pengetahuan yang dimiliki oleh siswa dengan bacaan yang dibaca agar siswa dapat memahami bacaan tersebut dengan tepat. Oleh karena itu, dalam kegiatan pembelajaran membaca diperlukan adanya model pembelajaran yang tepat dalam membelajarkan membaca pada siswa.

Salah satu model pembelajaran yang dapat digunakan dalam membelajarkan membaca adalah model Survey, Question, Reading, Reflect, Recite, Review (SQ4R). Ngalimun (2013:171) menyatakan bahwa "SQ4R adalah pengembangan dari SQ3R dengan menambahkan unsur Reflect, yaitu aktivitas memberikan contoh dari bahan bacaan dan membayangkan konteks aktual yang relevan". Menurut Shoimin (2014) terdapat beberapa kelebihan dari model SQ4R, yaitu 1) dengan adanya tahap survei pada awal pembelajaran, hal ini membangkitkan rasa ingin tahu siswa tentang materi yang akan dipelajari sehingga dapat meningkatkan motivasi siswa dalam belajar, 2) siswa diberi kesempatan mengajukan pertanyaan dan mencoba menemukan jawaban dari pertanyaannya sendiri dengan melakukan kegiatan membaca. Dengan demikian, dapat mendorong siswa berpikir kritis, aktif dalam belajar dan pembelajaran yang bermakna, 3) materi yang dipelajari siswa melekat untuk periode waktu yang lebih lama.

Penelitian ini dikuatkan dengan penelitian sebelumnya Yusniar Rasjid (2015) menyatakan bahwa Hasil penelitian yang dilakukan menunjukkan (1) Ada pengaruh signifikan model pembelajaran SQ4R dengan metode Talking Stick terhadap keterampilan metakognisi siswa, (2) Ada pengaruh signifikan model pembelajaran SQ4R dengan metode Talking Stick terhadap hasil belajar biologi siswa. Martinah Iin (2017) Juga menyatakan bahwa terdapat pengaruh model pembelajaran Survey Question Read Recite 
Review Reflect (SQ4R) terhadap pemahaman konsep matematis siswa kelas VIII SMP Negeri 2 Lubuklinggau Tahun Pelajaran 2017/2018. Hal senada juga di ungkapkan oleh Ibrahim (2017) Menyimpulkan bahwa hasil belajar matematika siswa kelas VII MTs Negeri Lubuklinggau setelah mengikuti pembelajaran matematika dengan model Survey, Question, Read, Reflect, Ricite, Review (SQ4R) secara signifikan tuntas. Rata-rata nilai tes akhir sebesar 80,20. Risky Nanda (2015) juga menyatakan bahwa Penerapan pembelajaran SQ4R mampu membantu meningkatkan hasil belajar sejarah siswa kelas VII SMP Empu Tantular Semarang. Hal ini dapat dilihat dari rata-rata hasil belajar IPS sejarah siswa yang meningkat dari hasil sebelum dilakukan pembelajaran SQ4R di kelas eksperimen diperoleh nilai dari 69,25 menjadi 76,07, sedangkan di kelas kontrol hanya meningkat dari 66,83 menjadi 70,6. Diora Gustina (2018) Menyimpulkan bahwa "Ada pengaruh positif yang cukup berarti atau sedang yaitu 0,50 dari Model Survey, Question,Read, Recite, Reflect, Review, (SQ4R) terhadap Motivasi Belajar Siswa Pada Mata Pelajaran Sejarah Kelas XI IPS SMA Negeri 1 Banjit Tahun Ajaran 2017/2018.

Penelitian ini dilaksanakan di SD Gugus Kompyang Sujana, Kecamatan Denpasar Barat dengan tujuan untuk mengetahui pengaruh yang signifikan model model Survey, Question, Reading, Reflect, Recite, Review terhadap keterampilan membaca pada siswa kelas V SD Gugus Kompyang Sujana Kecamatan Denpasar Barat Tahun Ajaran 2017/2018.

\section{Metode}

Penelitian ini dilaksanakan di SD Negeri Gugus Kompyang Sujana Kecamatan Denpasar Barat. Penelitian ini dirancang pada kelas V semester genap tahun ajaran 2017/2018. Rancangan penelitian yang digunakan dalam penelitian ini adalah penelitian kuantitatif dengan desain eksperimen semu (quasi eksperimental design) dalam bentuk nonequivalent control group design.

Dalam desain ini terdapat dua kelompok, yaitu kelompok eksperimen dan kelompok kontrol. Kedua kelompok diberikan pre-test dan post-test. Dalam penelitian ini pre-test diberikan pada kelompok eksperimen dan kelompok kontrol sebagai penyetaraan kelompok. Selanjutnya pada kelompok eksperimen diberikan perlakuan berupa model pembelajaran SQ4R, sedangkan pada kelompok kontrol tidak diberikan perlakuan atau dengan kata lain dibelajarkan dengan pembelajaran konvensional melalui pendekatan saintifik. Setelah diberikan perlakuan, kelompok eksperimen dan kelompok kontrol diberikan post-test untuk memperoleh data keterampilan membaca.

Populasi dalam penelitian ini adalah seluruh siswa Kelas V SD Negeri Gugus Kompyang Sujana Kecamatan Denpasar Barat yang berjumlah 638 orang siswa. Berdasarkan karakteristik populasi dan tidak bisa dilakukannya pengacakan individu, maka dalam penelitian ini sampel dari populasi diambil dengan teknik simple random sampling yang dirandom kelasnya. Teknik simple random sampling merupakan pengambilan anggota sampel dari populasi dilakukan secara acak tanpa memperhatikan strata yang ada dalam populasi itu. Cara demikian dilakukan bila anggota populasi dianggap homogen (Sugiyono, 2016). Pengambilan sampel dalam penelitian ini dilakukan dengan cara pengundian secara acak. Setelah dilakukan pengundian, diperoleh hasil kelas V A SD Negeri 12 Padangsambian dengan jumlah 42 orang siswa sebagai kelompok eksperimen dan kelas V A SD Negeri 9 Padangsambian dengan jumlah 44 orang siswa sebagai kelompok kontrol.

Data yang dikumpulkan dalam penelitian ini adalah data keterampilan membaca pada siswa kelas $\mathrm{V}$ SD Gugus Kompyang Sujana Kecamatan Denpasar Barat tahun ajaran 2017/2018. Terdapat dua aspek yang akan diteliti dalam keterampilan membaca, yakni keterampilan membaca pemahaman dan keterampilan membaca nyaring. Kedua aspek tersebut dikumpulkan melalui metode tes, yaitu tes tertulis dan tes praktik. Tes tertulis yang digunakan untuk menilai keterampilan membaca pemahaman berupa tes objektif dalam bentuk pilihan ganda biasa. Sedangkan untuk menilai keterampilan membaca nyaring menggunakan rubrik penilaian keterampilan membaca nyaring. Kedua hasil tes tersebut dikolaborasikan untuk mengukur penguasaaan keterampilan membaca pada siswa.

Sebelum tes diberikan kepada kedua kelompok sampel, dilakukan pengujian terhadap tes tersebut untuk mendapatkan gambaran secara teoritis dan empirik mengenai kelayakan tes tersebut sebagai instrumen penelitian. Uji instrumen secara teoritis dilakukan dengan menggunakan kisi-kisi dan dikonsultasikan dengan para ahli. Sedangkan secara empirik tes tersebut diujicobakan kepada responden sebanyak 42 orang siswa. Dari hasil uji instrumen yang meliputi uji validias, uji daya beda, indeks kesukaran, dan uji reliabilitas diperoleh 20 butir tes yang dinyatakan layak untuk digunakan dalam penelitian dari 30 butir tes yang diujicobakan.

Metode analisis data dalam penelitian ini meliputi analisis statistik deskriptif dan analisis statistik inferensial. Sugiyono (2016:207) menyebutkan "statistik deskriptif adalah statistik yang digunakan untuk menganalisis data dengan cara mendeskripsikan atau menggambarkan data yang telah terkumpul sebagaimana adanya tanpa bermaksud membuat kesimpulan yang berlaku untuk umum atau 
generalisasi". Teknik analisis data deskriptif dalam penelitian ini digunakan untuk mendeskripsikan data keterampilan membaca pada siswa yang dibelajarkan dengan model pembelajaran SQ4R dan keterampilan membaca pada siswa yang dibelajarkan dengan pembelajaran konvensional melalui pendekatan saintifik. Data keterampilan membaca pada siswa kelompok eksperimen dan kelompok kontrol disajikan secara deskriptif untuk mengetahui nilai rata-rata (mean), varians, dan standar deviasi.

Analisis statistik inferensial merupakan teknik analisis data yang digunakan untuk menentukan sejauh mana kesamaan antara hasil yang diperoleh dari suatu sampel dengan hasil yang didapatkan pada populasi keseluruhan. Pada penlitian ini, sebelum dilakukan uji hipotesis terlebih dahulu dilakukan uji prasyarat analisis yang meliputi uji normalitas sebaran data dan uji homogenitas varians. Uji normalitas sebaran data dalam penelitian ini menggunakan rumus Chi-kuadrat $\left(\chi^{2}\right)$ dengan kriteria pengujian pada taraf signifikansi $5 \%$ dan dk $=5$ adalah jika $\chi_{\text {hitung }}^{2} \leq \chi_{\text {tabel }}^{2}$ maka distribusi data dinyatakan normal, sedangkan jika $\chi_{\text {hitung }}^{2}>\chi_{\text {tabel }}^{2}$ maka distribusi data dinyatakan tidak normal. Uji homogenitas varians dilakukan dengan uji $\mathrm{F}$ dengan kriteria pengujian pada taraf signifikansi $5 \%$ dengan dk untuk pembilang = $\mathrm{n}_{1}-1$ dan dk untuk penyebut $=\mathrm{n}_{2}-1$, jika $\mathrm{F}_{\text {hitung }}<\mathrm{F}_{\text {tabel }}$ maka varians kedua kelompok data adalah homogen. Sebaliknya jika $F_{\text {hitung }}>F_{\text {tabel }}$ maka kedua kelompok data dinyatakan tidak homogen (heterogen).

Jika data yang diperoleh telah memenuhi uji prasyarat analisis selanjutnya dilakukan uji hipotesis dengan analisis statistik parametrik. Analisis statistik yang digunakan untuk menguji hipotesis penelitian ini adalah uji-t dengan rumus polled varians. Dengan kriteria jika harga $t_{\text {hitung }} \leq t_{\text {tabel, }}$, maka $H_{0}$ yang berbunyi tidak terdapat perbedaan yang signifikan keterampilan membaca antara kelompok siswa yang dibelajarkan menggunakan model pembelajaran SQ4R dan kelompok siswa yang dibelajarkan menggunakan pembelajaran konvensional pada siswa kelas V SD Gugus Kompyang Sujana Kecamatan Denpasar Barat Tahun Ajaran 2017/2018 diterima dan $\mathrm{H}_{\mathrm{a}}$ ditolak, dan jika harga $\mathrm{t}_{\text {hitung }}>\mathrm{t}_{\text {tabel }}$ maka $\mathrm{H}_{0}$ ditolak dan $\mathrm{H}_{\mathrm{a}}$ diterima pada taraf signifikansi $5 \%$ dengan $\mathrm{dk}=\mathrm{n}_{1}+\mathrm{n}_{2}-2$.

\section{Hasil dan Pembahasan}

Berdasarkan hasil post-test data keterampilan membaca pada 42 orang siswa di kelompok eksperimen menunjukkan bahwa nilai tertinggi yang diperoleh siswa adalah 92,5 dan nilai terendah yang diperoleh siswa adalah 55. Dari sebaran data tersebut diperoleh rata-rata (mean) sebesar 79,64 yang termasuk kriteria baik (B) setelah dikonsultasikan dengan tabel konversi PAP skala lima. Varians data keterampilan membaca pada siswa kelompok eksperimen adalah 85,30 dengan standar deviasi 9,24. Data keterampilan membaca pada siswa pada kelompok eksperimen disajikan dalam histogram berikut.

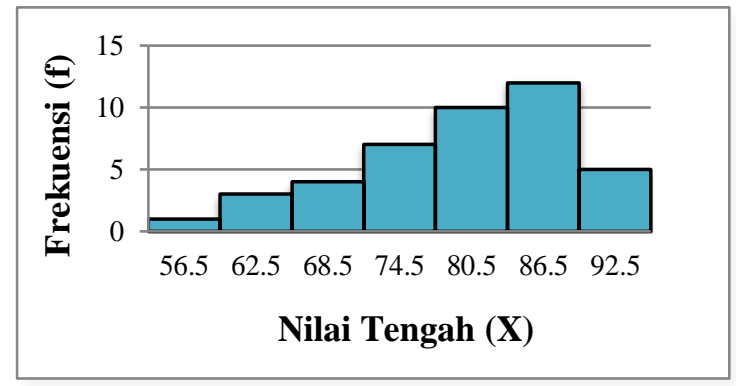

Gambar 1. Histogram Data Keterampilan Membaca Siswa Kelompok Eksperimen

Berdasarkan histogram tersebut dapat dideskripsikan bahwa frekuensi pada kelas interval pertama dengan nilai tengah 56,5 sebanyak 1 orang, frekuensi pada kelas interval kedua dengan nilai tengah 62,5 sebanyak 3 orang, frekuensi pada kelas interval ketiga dengan nilai tengah 68,5 sebanyak 4 orang, frekuensi pada kelas interval keempat dengan nilai tengah 74,5 sebanyak 7 orang, frekuensi pada kelas interval kelima dengan nilai tengah 80,5 sebanyak 10 orang, frekuensi pada kelas interval keenam dengan nilai tengah 86,5 sebanyak 12 orang, dan frekuensi pada kelas interval ketujuh dengan nilai tengah 92,5 sebanyak 5 orang. Kelas interval dengan frekuensi tertinggi terletak pada nilai tengah 86,5 dan kelas interval dengan frekuensi terendah terletak pada nilai tengah 56,5 .

Berdasarkan hasil post-test data keterampilan membaca pada 44 orang siswa di kelompok kontrol menunjukkan bahwa nilai tertinggi yang diperoleh siswa adalah 90 dan nilai terendah yang diperoleh siswa adalah 40. Dari sebaran data tersebut diperoleh rata-rata (mean) sebesar 72,05 yang termasuk kriteria cukup (C) setelah dikonsultasikan dengan tabel konversi PAP skala lima. Varians data 
keterampilan membaca pada siswa kelompok kontrol adalah 126,21 dengan standar deviasi 11,23. Data keterampilan membaca pada siswa pada kelompok eksperimen disajikan dalam histogram berikut.

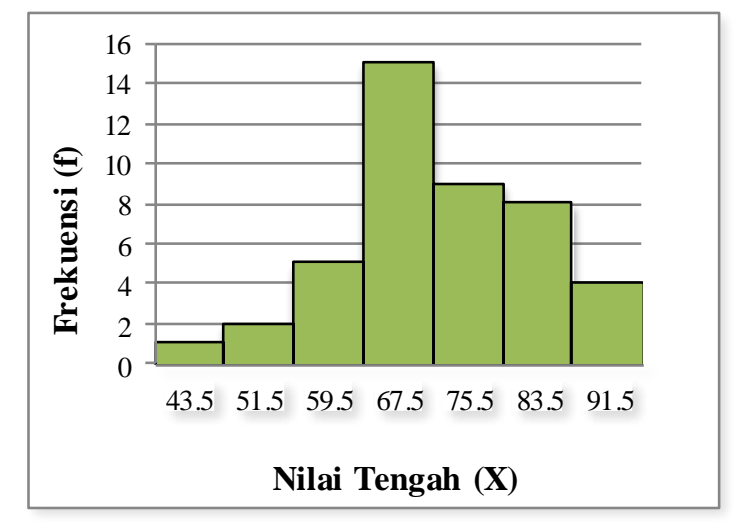

Gambar 2. Histogram Data Keterampilan Membaca Siswa Kelompok Kontrol

Berdasarkan histogram tersebut dapat dideskripsikan bahwa frekuensi pada kelas interval pertama dengan nilai tengah 43,5 sebanyak 1 orang, frekuensi pada kelas interval kedua dengan nilai tengah 51,5 sebanyak 2 orang, frekuensi pada kelas interval ketiga dengan nilai tengah 59,5 sebanyak 5 orang, frekuensi pada kelas interval keempat dengan nilai tengah 67,5 sebanyak 15 orang, frekuensi pada kelas interval kelima dengan nilai tengah 75,5 sebanyak 9 orang, frekuensi pada kelas interval keenam dengan nilai tengah 83,5 sebanyak 8 orang, dan frekuensi pada kelas interval ketujuh dengan nilai tengah 91,5 sebanyak 4 orang. Kelas interval dengan frekuensi tertinggi terletak pada nilai tengah 67,5 dan kelas interval dengan frekuensi terendah terletak pada nilai tengah 43,5.

Sebelum dilakukan pengujian hipotesis, dilakukan uji prasyarat yang meliputi uji normalitas sebaran data dan uji homogenitas varians. Uji normalitas dimaksudkan untuk mengetahui apakah sebaran data skor keterampilan membaca pada siswa pada kelompok eksperimen dan kelompok kontrol berdistribusi normal atau tidak sehingga dapat menenetukan teknik analisis datanya.

Berdasarkan hasil uji normalitas kelompok eksperimen, diperoleh Chi Kuadrat hitung $\left(\chi^{2}\right.$ hitung $)=$ 8,380 kemudian nilai tersebut dibandingkan dengan Chi Kuadrat tabel pada taraf signifikansi 5\% dengan $\mathrm{dk}=5,\left(\chi^{2}\right.$ tabel $)=11,070$. Hal ini menunjukkan bahwa $\chi^{2}{ }_{\text {hitung }}<\chi^{2}{ }_{\text {tabel }}$ berarti data keterampilan membaca pada siswa kelompok eksperimen berdistribusi normal.

Berdasarkan hasil uji normalitas kelompok kontrol, diperoleh Chi Kuadrat hitung ( $\chi^{2}$ hitung) $=$ 1,569 kemudian nilai tersebut dibandingkan dengan Chi Kuadrat tabel pada taraf signifikansi $5 \%$ dengan $\mathrm{dk}=5,\left(\chi^{2}\right.$ tabel $)=11,070$. Hal ini menunjukkan bahwa $\chi^{2}$ hitung $<\chi^{2}$ tabel berarti data keterampilan membaca pada siswa kelompok kontrol berdistribusi normal.

Pengujian homogenitas varians antar kelompok dimaksudkan untuk meyakinkan bahwa perbedaan yang diperoleh uji-t benar - benar berasal dari perbedaan antar kelompok bukan disebabkan oleh perbedaan di dalam kelompok. Dari hasil analisis diperoleh $F_{\text {hitung }}=1,48$. Hasil ini kemudian dibandingkan dengan $\mathrm{F}_{\text {tabel }}$ dengan dk pembilang $42-1=41$ dan dk penyebut $44-1=43$ dengan taraf signifikansi 5\%, sehingga diperoleh $\mathrm{F}_{\text {tabel }}=1,66$. Hal ini berarti $\mathrm{F}_{\text {hitung }}<\mathrm{F}_{\text {tabel }}$, sehingga data kelompok eksperimen dan kelompok kontrol memiliki varians yang homogen.

Berdasarkan hasil uji prasyarat yang terdiri dari uji normalitas sebaran data dan uji homogenitas varians, disimpulkan bahwa data kedua kelompok sampel berdistribusi normal dan memiliki varians yang homogen. Dengan demikian, uji hipotesis menggunakan uji-t dengan rumus polled varians dapat dilakukan.

Berdasarkan uji hipotesis diperoleh $t_{\text {hitung }}=3,396$ sedangkan pada taraf signifikansi $5 \%$ dengan $\mathrm{dk}$ $=84$ diperoleh nilai $t_{\text {tabel }}=2,00$ sehingga $t_{\text {hitung }}=3,396>t_{\text {tabel }}=2,00$. Dengan demikian, hipotesis nol $\left(H_{0}\right)$ ditolak. Hal ini menunjukkan bahwa terdapat perbedaan yang signifikan keterampilan membaca antara kelompok siswa yang dibelajarkan menggunakan model pembelajaran SQ4R dan kelompok siswa yang dibelajarkan menggunakan pembelajaran konvensional pada siswa kelas V SD Gugus Kompyang Sujana Kecamatan Denpasar Barat Tahun Ajaran 2017/2018. Berdasarkan hasil post-test yang telah diberikan kepada kedua kelompok sampel penelitian, diperoleh hasil perhitungan analisis data yang menunjukkan bahwa nilai rata-rata dari kelompok siswa yang mengikuti pembelajaran melalui model pembelajaran SQ4R memperoleh nilai rata-rata sebesar $\bar{X}=79,64$, sedangkan kelompok siswa yang mengikuti 
pembelajaran konvensional memperoleh nilai rata-rata sebesar $\bar{X}=72,05$. Jadi nilai rata-rata dari kedua kelompok memiliki perbedaan sebesar 7,59.

Berdasarkan hasil temuan tersebut, dapat dinyatakan kedua kelompok sampel penelitian yang memiliki kemampuan setara, setelah diberikan perlakuan berupa pembelajaran dengan model pembelajaran SQ4R dan mengikuti pembelajaran menggunakan pendekatan saintifik diperoleh hasil penguasaan keterampilan membaca yang berbeda. Hal ini dapat dilihat dari rata - rata siswa yang mengikuti pembelajaran menggunakan model pembelajaran SQ4R lebih tinggi dibandingkan dengan rata rata siswa yang mengikuti pembelajaran konvensional, yaitu melalui pendekatan saintifik. Perbedaan hasil penguasaan keterampilan membaca dengan perolehan nilai rata-rata yang lebih tinggi pada kelompok eksperimen dibandingkan kelompok kontrol disebabkan oleh perlakuan berupa model pembelajaran SQ4R yang diberikan pada kelompok eksperimen.

Model pembelajaran SQ4R merupakan model pembelajaran yang digunakan untuk menuntun siswa belajar secara secara aktif, kritis, dan sistematis sehingga siswa dapat mengingat dan mengaplikasikan pengetahuan yang telah di peroleh melalui tahapan survey (penelitian pendahuluan), question (bertanya), reading (membaca), reflect (memberikan contoh), recite (mempertimbangkan jawaban), dan review (meninjau ulang). Dengan adanya tahap survei pada awal pembelajaran, hal ini membangkitkan rasa ingin tahu siswa tentang materi yang akan dipelajari sehingga dapat meningkatkan motivasi siswa dalam belajar. Siswa juga diberi kesempatan mengajukan pertanyaan dan mencoba menemukan jawaban dari pertanyaannya sendiri dengan melakukan kegiatan membaca. Dengan demikian, dapat mendorong siswa berpikir kritis, aktif dalam belajar dan pembelajaran yang bermakna. Selain itu, dengan penerapan model SQ4R materi yang dipelajari siswa melekat untuk periode waktu yang lebih lama.

Hasil penelitian ini mendukung hasil penelitian sebelumnya yang disampaikan oleh Suardani (2013) yang menyatakan bahwa model pembelajaran SQ4R berpengaruh positif dan signifikan terhadap keterampilan membaca dalam pembelajaran Bahasa Indonesia siswa kelas V SD Gugus I Denpasar Selatan tahun pelajaran 2012/2013. Penelitian lain yang memiliki kesamaan dengan penelitian ini adalah penelitian yang dilakukan oleh Gunarsa (2018) yang menyatakan bahwa terdapat perbedaan kemampuan membaca pemahaman siswa antara kelompok siswa yang dibelajarkan dengan strategi SQ4R berbantuan Satua Bali dan kelompok siswa yang dibelajarkan tidak dengan strategi SQ4R berbantuan Satua Bali pada siswa kelas V di SD Gugus V Kintamani Tahun Ajaran 2017/2018.Berdasarkan paparan tersebut, dapat dikatakan bahwa model Survey, Question, Reading, Reflect, Recite, Review berpengaruh terhadap keterampilan membaca pada siswa kelas V SD Gugus Kompyang Sujana Kecamatan Denpasar Barat Tahun Pelajaran 2017/2018.

\section{Simpulan dan Saran}

Berdasarkan hasil analisis data keterampilan membaca sampel diperoleh $t_{\text {hitung }}=3,396$ sedangkan nilai $t_{\text {tabel }}$ pada taraf signifikansi $5 \%$ dengan derajat kebebasan $(\mathrm{dk}=42+44-2=84)$ adalah 2,00 . Karena $t_{\text {hitung }}>t_{\text {tabel }}(3,396>2,00)$ maka $\mathrm{H}_{0}$ yang berbunyi tidak terdapat perbedaan yang signifikan keterampilan membaca antara kelompok siswa yang dibelajarkan menggunakan model pembelajaran SQ4R dan kelompok siswa yang dibelajarkan menggunakan pembelajaran konvensional pada siswa kelas V SD Gugus Kompyang Sujana Kecamatan Denpasar Barat Tahun Ajaran 2017/2018 ditolak dan $\mathrm{H}_{\mathrm{a}}$ yang berbunyi terdapat perbedaan yang signifikan keterampilan membaca antara kelompok siswa yang dibelajarkan menggunakan model pembelajaran SQ4R dan kelompok siswa yang dibelajarkan menggunakan pembelajaran konvensional pada siswa kelas V SD Gugus Kompyang Sujana Kecamatan Denpasar Barat Tahun Ajaran 2017/2018 diterima. Jadi, dapat disimpulkan bahwa terdapat pengaruh yang signifikan model Survey, Question, Reading, Reflect, Recite, Review terhadap keterampilan membaca pada siswa kelas V SD Gugus Kompyang Sujana Kecamatan Denpasar Barat Tahun Ajaran 2017/2018.

Berdasarkan temuan penelitian, kepada guru disarankan agar lebih kreatif dan inovatif untuk memfasilitasi siswa dalam pembelajaran berupa sumber belajar dan kesempatan yang lebih besar bagi siswa dalam pembelajaran dengan menggunakan model Survey, Question, Reading, Reflect, Recite, Review sehingga tercipta pembelajaran bermakna dan menyenangkan bagi siswa. Sekolah hendaknya dapat menggunakan hasil penelitian ini sebagai pendukung sumber belajar guru untuk menunjang pembelajaran agar siswa semakin termotivasi untuk belajar sehingga sekolah mampu meningkatkan mutu sekolah melalui peningkatan kualitas dan hasil belajar siswa. Peneliti lain disarankan agar memanfaatkan hasil penelitian ini sebagai kajian penelitian relevan sebagai penunjang penelitian selanjutnya dengan kajian yang lebih luas dan mendalam mengenai model Survey, Question, Reading, Reflect, Recite, Review dalam kaitannya dengan hasil belajar baik kompetensi pengetahuan, sikap, maupun keterampilan. 


\section{Daftar Rujukan}

Dalman. 2013. Keterampilan Membaca. Jakarta: Rajawali Press.

Dhieni, dkk. 2014. Metode Pengembangan Bahasa. Tanggerang Selatan: Universitas Terbuka.

Diora Gustina. 2018. Pengaruh Model Pembelajaran Survey, Question, Read, Recite, Reflect, Review (SQ4R) terhadap Motivasi Belajar Siswa. Jurnal Pendidikan Sejarah Unnes. Vol.2 No.1.

Fadlillah. 2014. Implementasi Kurikulum 2013 Dalam Pembelajaran SD/MI, SMP/MTs, \& SMA/MA. Yogyakarta: Arr-Ruzz Media.

Gunarsa, I Made Deni. 2018. "Pengaruh Strategi SQ4R Berbantuan Satua Bali Terhadap Kemampuan Membaca Pemahaman Siswa Kelas V". E-Journal PGSD UniverstiasPendidikan Ganesha, Volume 6, Nomor 1 (hlm. 10-19). Tersedia pada https://ejournal.undiksha.ac.id/index.php/IPGSD/article/ view/12920/8178 (diakses pada tanggal 7 Januari 2018).

Ibrahim. 2017. Penerapan Model Survey, Question, Read, Reflect, Recite, Review (Sq4r) Pada Pembelajaran Matematika. Jurnal Matematika STKIP PGRI Lubuklinggau. Vol.2 No.2.

Iskandarwassid dan Dadang Sunendar. 2016. Strategi Pembelajaran Bahasa. Bandung: PT. Remaja Rosdakarya.

Martinah Iin. 2017. Pengaruh Model Pembelajaran Survey Question Read Recite Review Reflect (Sq4r) Terhadap Pemahaman Konsep Matematis. Jurnal Matematika STKIP PGRI Lubuklinggau. Vol.2 No.2.

Ngalimun. 2013. Strategi dan Model Pembelajaran. Yogyakarta: Aswaja Pressindo.

Rahim, Farida. 2011. Pengajaran Membaca di Sekolah Dasar. Jakarta: Bumi Aksara.

Risky Nanda. 2015. Pengaruh Penggunaan Model Pembelajaran Sq4r (Survey, Question, Read, Reflect, Recite, Review) Pada Pelajaran Ips Sejarah Terhadap Hasil Belajar. Jurnal Pendidikan Sejarah Unnes. Vol.2 No.1.

Runaitun. 2015. "Penggunaan Strategi SQ4R (Survey, Question, Read, Reflect, Recite, Review) Untuk Meningkatkan Keterampilan Membaca Pemahaman". Jurnal PGSD FKIP Universitas Sebelas Maret, Volume 4, Nomor $11 \quad$ (hlm. 1-6). $\quad$ Tersedia pada http://www.jurnal.fkip.uns.ac.id/index.php/pgsdsolo/article/view/8865/6687 (diakses pada tanggal 20 Januari 2018).

Shoimin, Aris. 2014. 68 Model Pembelajaran Inovatif dalam Kurikulum 2013. Yogyakarta: Ar-Ruzz Media.

Solehan, dkk. 2014. Pendidikan Bahasa Indonesia di SD. Tanggerang Selatan: Universitas Terbuka.

Suardani, Ni Luh Ade. 2013. "Pengaruh Model Pembelajaran SQ4R Terhadap Keterampilan Membaca Dalam Pembelajaran Bahasa Indonesia Siswa Kelas V SD Gugus I Denpasar Selatan”. Jurnal Mimbar PGSD Universitas Pendidikan Ganesha, Volume 1, Nomor 1 (hlm. 1-9). Tersedia pada https://ejournal.undiksha.ac. id/ index.php/IJPGSD/article/view/968/838 (diakses tanggal 2 Januari 2018).

Sugiyono. 2016. Metode Penelitian Pendidikan Pendekatan Kuantitatif, Kualitatif, Dan R\&D. Bandung: Alfabeta.

Susanto, Ahmad. 2015. Teori Belajar Dan Pembelajaran Di Sekolah Dasar. Jakarta: Prenadamedia Group.

Tarigan, Henry Guntur. 2015. Membaca sebagai Suatu Keterampilan Berbahasa. Bandung: CV Angkasa. 
Yusniar Rasjid. 2015. Pengaruh Model Pembelajaran Survey Question Read Reflect Recite Review (Sq4r) Dengan Metode Talking Stick Terhadap Keterampilan Metakognisi Dan Hasil Belajar Biologi Siswa Sman 9 Makassar. Jurnal Biotek Universitas Islam Negeri Alauddin Makassar. Vol. 3 No.2. 